\title{
Secondary lahar hazard assessment for Villa la Angostura, Argentina, using Two-Phase-Titan modelling code during 2011 Cordón Caulle eruption
}

\author{
G. Córdoba ${ }^{1}$, G. Villarosa ${ }^{2}$, M. F. Sheridan ${ }^{3}$, J. G. Viramonte ${ }^{4}$, D. Beigt ${ }^{2}$, and G. Salmuni ${ }^{5}$ \\ ${ }^{1}$ Universidad de Nariño, Pasto, Colombia \\ ${ }^{2}$ Universidad del Comahue, INIBIOMA, Bariloche, Argentina \\ ${ }^{3}$ SUNY University at Buffalo, Buffalo, NY, USA \\ ${ }^{4}$ Universidad Nacional de Salta, INENCO-GEONORTE-UNSa-CONICET, Salta, Argentina \\ ${ }^{5}$ Comisión Nacional de Actividades Espaciales, CONAE, Salta, Argentina
}

Correspondence to: G. Córdoba (gcordobaguerrero@gmail.com)

Received: 14 August 2014 - Published in Nat. Hazards Earth Syst. Sci. Discuss.: 7 October 2014

Revised: 25 February 2015 - Accepted: 27 February 2015 - Published: 8 April 2015

\begin{abstract}
This paper presents the results of lahar modelling in the town of Villa La Angostura (Neuquén-Argentina) based on the Two-Phase-Titan modelling computer code. The purpose of this exercise is to provide decision makers with a useful tool to assess lahar hazard during the 2011 PuyehueCordón Caulle Volcanic Complex eruption. The possible occurrence of lahars mobilized from recent ash falls that could reach the city was analysed. The performance of the TwoPhase-Titan model using $15 \mathrm{~m}$ resolution digital elevation models (DEMs) developed from optical satellite images and from radar satellite images was evaluated. The output of these modellings showed inconsistencies that, based on field observations, were attributed to bad adjustment of the DEMs to real topography. Further testing of results using more accurate radar-based $10 \mathrm{~m}$ DEM, provided more realistic predictions. This procedure allowed us to simulate the path of flows from Florencia, Las Piedritas and Colorado creeks, which are the most hazardous streams for debris flows in Villa La Angostura. The output of the modelling is a valuable tool for city planning and risk management especially considering the glacial geomorphic features of the region, the strong urban development growth and the land occupation that has occurred in the last decade in Villa La Angostura and its surroundings.
\end{abstract}

\section{Introduction}

After decades of quiescence, the Cordon Caulle volcanic complex in the Chilean Southern Andes began an eruptive process at 14:45 LT on 4 June 2011 (Elissondo et al., 2011) from the new vent named "We Pillan" (New Crater in Mapuche language) (Collini et al., 2012). This vent is located in the Southern Volcanic Zone (SVZ) at $40.58^{\circ} \mathrm{S}$ and $72.13^{\circ} \mathrm{W}$, and $2240 \mathrm{~m}$ a.m.s.l. (above mean sea level) (Lara and Moreno, 2006). The subplinian eruption produced a large plume of gases and ash particles that reached $12 \mathrm{~km}$ in height (Fig. 1) which eventually circled the Southern Hemisphere disrupting air travel on several continents. As typically occurs in mid-latitude Central and South Andean eruptions (Villarosa et al., 2006; Folch et al., 2008; Collini et al., 2012), the dominant regional winds directed the ash clouds over the Andes and caused abundant ash fallout across the Argentinean provinces of Río Negro, Neuquén and Chubut (affecting the more proximal areas in Chile as well). Large quantities of ash fell in the nearby regions until the end of July, causing major problems in villages and cities of the Patagonian Andes and permanent closure of airports. Villa la Angostura, one of the most tourist areas of Patagonia, located near the Argentine-Chilean border and a short distance from the new vent, was one of the cities most affected by this eruption.

As a consequence of these ash fall events, thick deposits of tephra and snow accumulated during the winter covering ex- 


\section{S.H.N.-S.M.N. "Niveles de Vuelo FL100"}

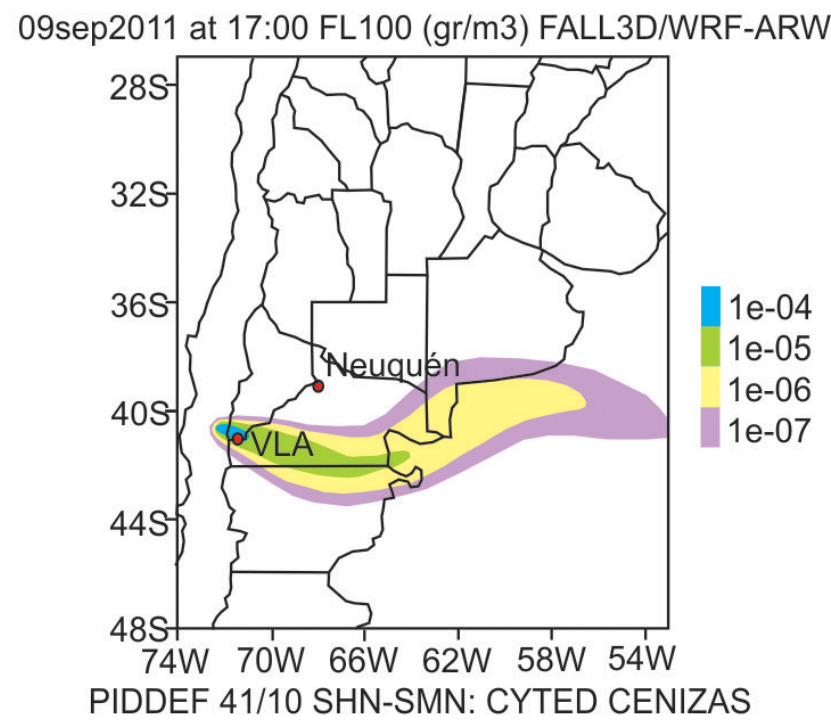

09sep2011.17

Figure 1. Fall 3-D program of ash dispersion modelling of the Cordón Caulle complex 2011 eruption. The coloured representation shows its subplinian plume dispersion for 9 June 2011 (after Collini et al., 2012).

tensive areas surrounding Villa La Angostura. This resulted in a lahar hazard for the town, as the snow began to melt during the spring and summer seasons. This paper analyses the hazard posed by the snow-ash deposits/pack that could contribute to lahar formation potentially affecting Villa $\mathrm{La}$ Angostura.

\section{Volcanic event and deposits}

On 27 April 2011 the Chilean OVDAS-SERNAGEOMIN Institute (OVDAS-SERNAGEOMIN, 2011a) reported that a swarm of volcano-tectonic earthquakes, centred on the Cordón Caulle fissure zone, had been detected. These earthquakes continued to increase in magnitude and frequency until Saturday 4 June, when the eruption sequence began (OVDAS-SERNAGEOMIN, 2011b). At 13:00 LT, an earthquake followed by a strong blast surprised neighbours at Villa La Angostura, $45 \mathrm{~km}$ east-southeast of the vent, and a $5 \mathrm{~km}$ wide ash and gas plume rose to more than $12 \mathrm{~km}$ height (Fig. 1). Then, coarse ash fall occurred soon after in the villa and by 16:30 LT the plume reached San Carlos de Bariloche, located $100 \mathrm{~km}$ SE of the vent producing a dense coarse ash pyroclastic fall. A sampling network was set up to collect direct fall tephra from the beginning of the eruption, covering a transect from Paso Puyehue, on the Chile-Argentina border, Villa La Angostura, Bariloche and to the steppe as far as Ingeniero Jacobacci in Río Negro Province.

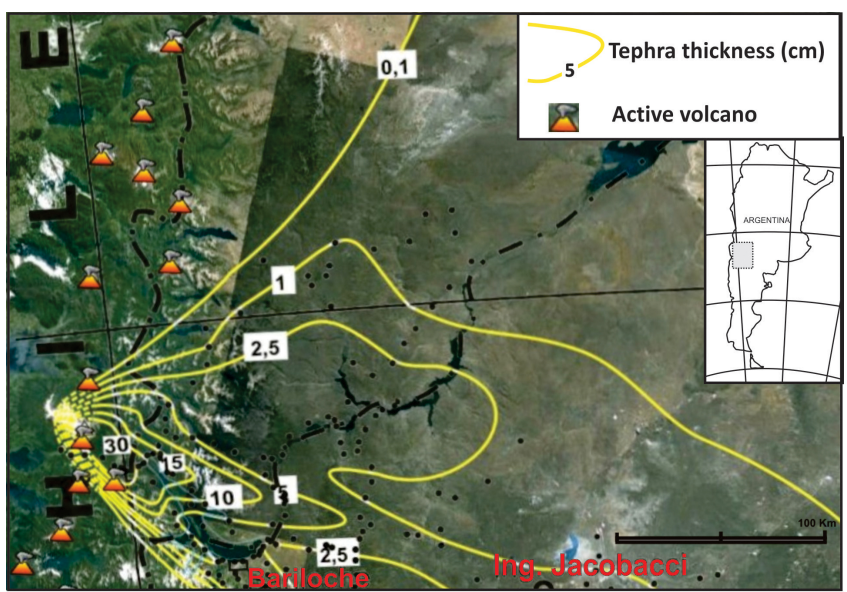

Figure 2. Isopach and affected area by the end of 2 October. The yellow lines are the isopach contours. The dots are the sampling sites (after Villarosa and Outes, 2013).

Over 400 thickness data were plotted to make an isopach map (Fig. 2). The most relevant characteristic of the first pulses of the eruption that is seen clearly from the map is a distribution pattern showing three main deposition axes that correspond to the dispersion directions of the main plumes at 90,110 and $130^{\circ}$. Deposited materials during the period June-October 2011 affected more than $1450 \mathrm{~km}^{2}$ with at least $10 \mathrm{~cm}$ thick ash, and $170 \mathrm{~km}^{2}$ were covered by more than $30 \mathrm{~cm}$ thick tephra. Direct tephra fall in the basins of the streams draining towards Villa La Angostura accumulated more than $15 \mathrm{~cm}$ (up to $30 \mathrm{~cm}$ in some cases) forming thick deposits along the dispersion axis. Soon after deposition, remobilization of tephra by wind and rain in high slopes was evident.

Tephra deposited during the first eruptive pulse was characterized by well-sorted coarse ash and lapilli layers composed of high vesicular pumice with subordinated lithics. The deposit formed during the first days of the eruption was coarse-grained, mainly composed of lapilli and coarse ash with the main fraction in the range $500 \mu \mathrm{m}-1.5 \mathrm{~mm}$. By 8 June samples were finer grained with almost $50 \%$ of particles between 500 and $63 \mu \mathrm{m}$. The grain size distribution of samples collected during 12-14 June was even finer, with almost $40 \%$ of particles $<63 \mu \mathrm{m}$.

Subsequent explosive pulses produced several coarse to fine ash tephra deposits, frequently separated by thin compact, very fine ash layers. This alternation of thick, coarse unconsolidated and well-sorted tephra with thin, fine, compacted ash showed different degrees of stability in high slopes and differential behaviour when exposed to erosion.

The eruption occurred during the austral winter, which is the rainy season in the Andean North Patagonia region (average rainfall between 4000 and $2500 \mathrm{~mm} \mathrm{yr}^{-1}$; Barros et al., 1983). Important masses of unconsolidated ash deposits were remobilized by rain and wind and were covered by snow soon 
after the deposition, forming a snowpack characterized by several centimetres to tens of centimetres thick snow layers intercalated with subcentimetre to $5 \mathrm{~cm}$ thick ash/lapilli layers. According to traditional snow avalanche tests performed in the field (shovel shear and stability tests; Villarosa, et al., 2012) these snow/tephra deposits proved to be very unstable. Well-sorted coarse ash and lapilli tephras are low cohesive layers that frequently work as failure layers in the snowpack, producing snow avalanches that carry and deposit downhill important masses of tephra. The instability of the ash and snow deposits in the upper basins, characterized by highsloped valley walls of glacial origin, was later confirmed by several snow and ash avalanches that were recorded in the area during July and August 2011. In those conditions, mobilization of tephra occurred rather quickly, accumulating reworked materials on the valley floor, 2 or 3 times thicker than the original deposits.

On the other hand, fine ash frozen layers were identified as low-permeability horizons that prevent infiltration and enhance surface runoff. These factors could result in a combination of processes that lead to the generation of secondary lahars triggered by intense rainfall events. Rainfall accelerates snow melting; increased runoff produces high volumes of running water in the high fluvial basins; snow/ash avalanches and redeposited tephra in the valley floor make solid phase available for mass mobilization.

By the end of the spring most snow had disappeared, the pyroclastic material contained in the snowpack was almost completely transported downhill into the floor of the valleys and the finer fractions were intensely reworked by wind. As a result, thicknesses varied significantly compared to the original deposit, particularly in the heads of these $\mathrm{U}$ shaped valleys, determining a change in the original conditions used for the modelling. The resulting isopach map using data collected up to November 2012 shows these variations (Fig. 3). Therefore, results presented here are only valid for the dominating conditions during 2011 winter and spring, when secondary lahars were considered as a real hazard.

\section{Lahar hazard assessment}

In order to provide the decision makers with a reliable forecast of possible lahars from Florencia, Piedritas and Colorado creeks, we chose a modelling method which accounts for the current topography and uses geological records as initial conditions.

Due to the two-phase characteristics of debris flows, the chosen model must account for the two-phase behaviour of lahars (Iverson, 1997). In this case we used the Two-PhaseTitan model (Córdoba et al., 2015) which was developed at SUNY University at Buffalo. For the solids phase, this model is based on the early work of Savage and Hutter (1989), Iverson (1997) and Iverson and Denlinger (2001), who arrived at the insight that very large dense granular flows could be mod-

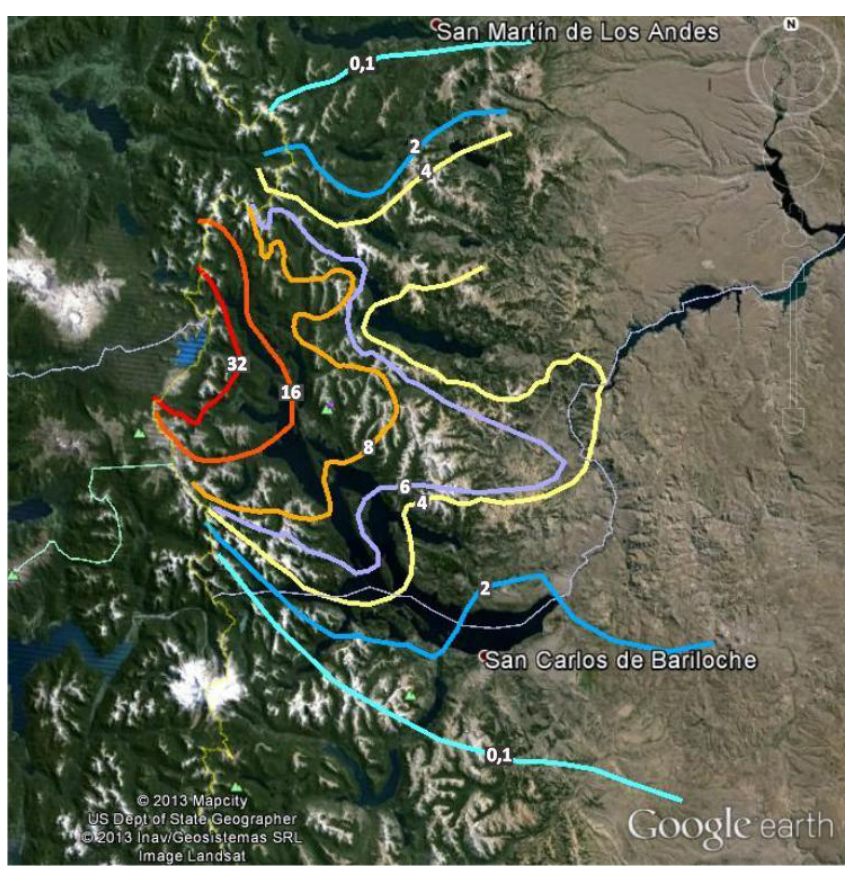

Figure 3. Distribution of tephra deposits modified by erosion and remobilization by November 2012; thicknesses expressed in centimetres (after Villarosa and Outes, 2013).

elled as incompressible continua governed by a Coulomb failure criterion (Coulomb, 1773). The fluid phase uses the typical hydraulic approach (Chow, 1969; Guo, 1995) together with the Colebrook-White equation (Colebrook and White, 1937) for the basal friction. The phases interact through a phenomenological interphase drag and a buoyancy term.

Further, the equations of motion are depth averaged, by assuming that the flow depth is very small in comparison to the runoff. This means that the resulting equations neglect vertical accelerations in a similar way to shallow-water approaches. By scaling the problem stating that $\epsilon=H / L$, where $H$ is the pile height and $L$ is runout length to the pile front, and neglecting higher-order terms in $\epsilon$, the corresponding equilibrium equations become (only the $x$-direction is shown):

1. conservation of mass:

$$
\partial_{t} \hat{h}+\partial_{x}\left(\hat{h}\left(\overline{\varphi v_{x}}+\overline{\varphi^{f} u_{x}}\right)\right)+\partial_{y}\left(\hat{h}\left(\overline{\varphi v_{y}}+\overline{\varphi^{f} u_{y}}\right)\right)=0 ;
$$


2. conservation of solid phase momentum:

$$
\begin{aligned}
\partial_{t}\left(\hat{h} \bar{\varphi} \overline{v^{x}}\right)+\partial_{x}\left(\hat{h} \bar{\varphi} \overline{v^{x} v^{x}}\right)+\partial_{y}\left(\hat{h} \bar{\varphi} \overline{v^{x} v^{y}}\right) \\
=-\frac{\epsilon}{2}\left(1-\frac{\rho^{f}}{\rho^{s}}\right) \partial_{x}\left(\alpha_{x x} \hat{h}^{2} \bar{\varphi}\left(-g^{z}\right)\right) \\
\quad-\frac{\epsilon}{2}\left(1-\frac{\rho^{f}}{\rho^{s}}\right) \partial_{y}\left(\alpha_{x y} \hat{h}^{2} \bar{\varphi}\left(-g^{z}\right)\right) \\
+\left(1-\frac{\rho^{f}}{\rho^{s}}\right)\left(-\epsilon \alpha_{x x} \partial_{x} b-\epsilon \alpha_{x y} \partial_{y} b+\alpha_{x z}\right) \\
\hat{h} \bar{\varphi}\left(-g^{z}\right)-\frac{\epsilon}{2} \frac{\rho^{f}}{\rho^{s}} \bar{\varphi} \partial_{x}\left(\hat{h}^{2}\left(-g^{z}\right)\right) \\
\quad-\epsilon \frac{\rho^{f}}{\rho^{s}} \hat{h} \bar{\varphi}\left(-g^{z}\right) \partial_{x} b+\left(\frac{\bar{D}}{\rho^{s}}\right)\left(\overline{u^{x}}-\overline{v^{x}}\right)+\hat{h} \bar{\varphi} g^{x}
\end{aligned}
$$

3. conservation of fluid phase momentum:

$$
\begin{aligned}
\partial_{t}\left(\hat{h} \overline{\varphi^{f}} \overline{u^{x}}\right)+\partial_{x}\left(\hat{h} \overline{u^{x}} \overline{\varphi^{f}} \overline{u^{x}}\right)+\partial_{y}\left(\hat{h} \overline{\varphi^{f}} \overline{u^{x} u^{y}}\right) \\
=-\frac{1}{2} \epsilon \partial_{x} \hat{h}^{2} \overline{\varphi^{f}}\left(-g^{z}\right)-\left(\frac{\bar{D}}{\rho^{\mathrm{s}}}\right)\left(\overline{u^{x}}-\overline{v^{x}}\right) \\
+\hat{h} \overline{\varphi^{f}} g^{x}+\overline{\varphi^{f}} C_{\mathrm{f}} u^{x}\|\mathbf{u}\| ;
\end{aligned}
$$

where $\bar{\varphi}$ is the solid volumetric concentration, and $\overline{\varphi^{f}}=$ $1-\bar{\varphi}$. The $\phi_{\text {int }}$ and $\phi_{\text {bed }}$ represent basal and internal friction angles, $\alpha_{x y}=-\operatorname{sgn}\left(\partial_{y} v\right), \alpha_{x x}=k_{\mathrm{ap}}, \alpha_{x z}=$ $-v^{*} \tan \left(\phi_{\text {bed }}\right) /\|\mathbf{v}\|$, where $k_{\text {ap }}$ relates the normal and tangential stresses. The $\hat{h}$ represents the depth of the flow, $\bar{v}^{x}$ and $\bar{v}^{y}$ the solid velocity field, $\bar{u}^{x}$ and $\bar{u}^{y}$ the fluid velocity field, $\rho^{\mathrm{s}}$ and $\rho^{\mathrm{f}}$ the solid and fluid densities. The $\epsilon$ is the ratio flow depth to flow length, $g$ is the gravity, $C_{\mathrm{f}}$ is the friction factor, and $D$ is the interphase drag coefficient. The solid and fluid momentum equations in the $y$-direction have a similar form. Note that if $\overline{\varphi^{f}} \rightarrow 1$, then Eq. (3) becomes the typical shallow-water approach of hydraulics (Chow, 1969). This means that the program can be used in both extremes, from a maximum pack concentration of $\varphi^{s}=0.65$ to concentrations as low as $\varphi^{s}=10^{-8}$ (almost pure water).

The model has the additional advantage of saving computer power, because it is a pseudo 3-D approach, which is also due to its mesh adapting capabilities. The program accuracy has been tested both on experimental-scale flows (Córdoba et al., 2015) and on natural-scale flows. We compared the program predictions with the field data taken by Williams et al. (2008) about the 2005 Vazcun Valley lahar, which happened on one of the slopes of Tungurahua volcano, Ecuador. Williams et al. (2008) developed a $5 \mathrm{~m}$ smooth digital elevation model (DEM) of the natural channel. In addition, they measured the super-elevation of the flow in a bend of the channel, and produced field estimates of the flow speed and flow volumes. We used an initial volumetric concentration of

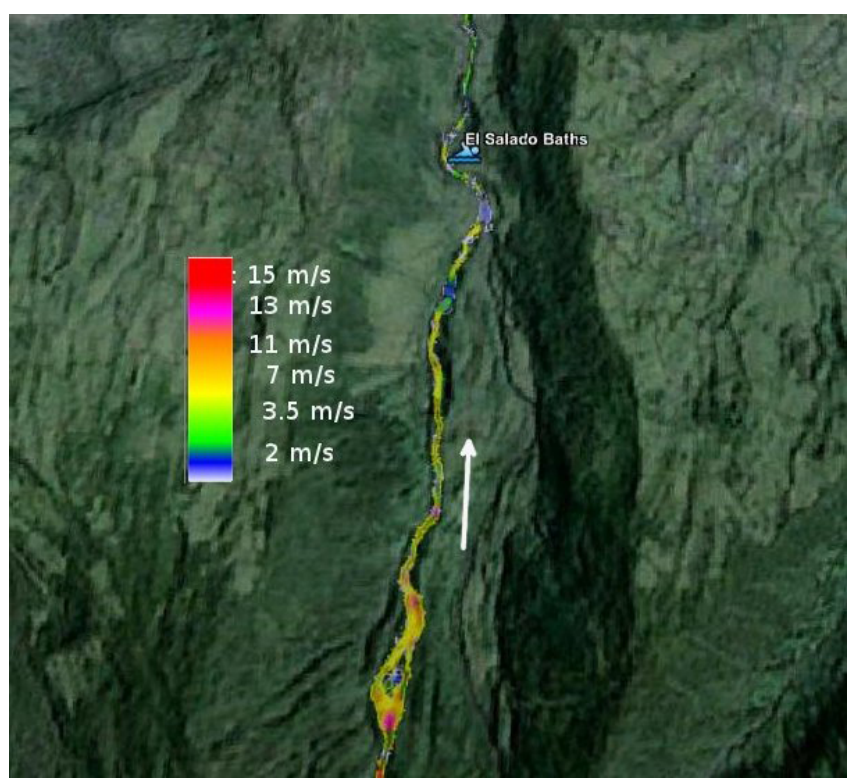

Figure 4. Distribution of the predicted speed for the 2005 Vazcun Valley lahar (Ecuador). The arrow shows the direction of the flow. The upper channel is located at the bottom of the figure. The lower channel corresponds to the El Salado Baths sector.

0.5 and an average of $60000 \mathrm{~m}^{3}$ as initial volume, which we located at the top of the Vazcun River basin. From seismic records Williams et al. (2008) estimated that the speed of the flow in the upper channel was about $7 \mathrm{~m} \mathrm{~s}^{-1}$, and $3.1 \mathrm{~m} \mathrm{~s}^{-1}$ in the lower channel. As can be seen in Fig. 4, Two-PhaseTitan predicts $7-8 \mathrm{~m} \mathrm{~s}^{-1}$ for the upper channel and $3.5 \mathrm{~m} \mathrm{~s}^{-1}$ at Salado Baths (lower channel). Thus, the program predictions about speed shows almost $90 \%$ accuracy. Figure 5 shows a profile of the flow at the bend where Williams et al. (2008) took their measurements (the bend just before El Salado Baths). The figure shows that the program predicts $6.5 \mathrm{~m}$ of super-elevation, whereas field cross-sections show $5.5 \mathrm{~m}$, which shows that our predictions are $75 \%$ accurate.

Through the extended use of this program in real-scale problems, it has shown its reliability and robustness (Córdoba et al., 2010). Thus, in this work we use Two-PhaseTitan as the computational tool to study and forecast the lahar hazard in Villa la Angostura.

\subsection{Initial conditions}

We analysed the lahar hazard at Villa La Angostura from three drainages whose streams flow directly toward the urban area of the town. As can be seen in Fig. 6 they are Las Piedritas Creek, which have a catchment area of $7.75 \mathrm{~km}^{2}$, Colorado Creek, with a catchment area of $3.8 \mathrm{~km}^{2}$ and Florencia Creek, with a catchment area of $1.3 \mathrm{~km}^{2}$ (Baumann et al., 2011). The Two-Phase-Titan program needs the location of the piles, their initial volumes, the pile height and initial concentration of solids as initial conditions. 
Table 1. Calculated total volumes of deposited ash-snow material at each basin, and volumes used in the modelling, as well as the pile height used.

\begin{tabular}{lrrcc}
\hline Creek & $\begin{array}{r}\text { Total } \\
\text { volume } \\
(\mathrm{m})\end{array}$ & $\begin{array}{r}\text { Large } \\
\text { volumes } \\
(\mathrm{m})\end{array}$ & $\begin{array}{r}\text { Medium } \\
\text { volumes } \\
(\mathrm{m})\end{array}$ & $\begin{array}{r}\text { Pile } \\
\text { height } \\
(\mathrm{m})\end{array}$ \\
\hline Piedritas & 600000 & 300000 & 150000 & 1 \\
Colorado & 270000 & 200000 & 70000 & 1 \\
Florencia & 55500 & 50000 & 20000 & 1.5 \\
\hline
\end{tabular}

In order to set the initial volumetric fraction of solids, we used the actual ratio of snow and ash deposits from the eruption. Figure 7 shows several interlayered ash-snow deposits from the Cordón Caulle eruption. They show that almost $30 \%$ of them consist of the deposited ash. However, water rain and water of the streams added to the lahar reduce this fraction, but later erosion incorporates solid particles to the lahar, resulting in the opposite effect. Thus, we postulate that these effects become balanced or negligible which allow us to use as initial solids volumetric concentration $\varphi_{\mathrm{s}}=0.3$ for all the initial piles.

The data needed to set the initial volumes were taken from the Elissondo et al. (2011) and Baumann et al. (2011) reports, which analysed the deposits of the ash fall from the 4 July 2011 eruption of Cordón Caulle volcanic complex on the nearby mountains. Elissondo et al. (2011) estimated the amount of deposited material at each basin and Baumann et al. (2011) estimated the depth of the respective deposits.

Two cases were analysed for each creek - a high and a medium volume. As it is unlikely that all of the deposited material would instantaneously become a lahar in large catchments, we assumed different fractions of the total deposited volumes as initial volumes for each catchment. In the case of Las Piedritas Basin, we assumed as high initial volume the $50 \%$ of the total deposited material, and the quarter of all the deposited material as a medium volume. In the case of medium size catchment areas like Colorado, $75 \%$ of the deposited material is assumed as high volume. Finally, we assume that from the material deposited on small catchment areas, $90 \%$ could become part of the lahar. An other initial condition is the pile height. In this paper we use the reported material deposited depth, which is less than $1 \mathrm{~m}$ in all the basins (Elissondo et al., 2011; Baumann et al., 2011). However, we increased these values by a security factor, in order to account for other uncertainties. Table 1 summarizes the high and medium volumes, as well as the pile height used as initial conditions in our modelling.

The location of the initial piles of material were chosen at great distances from each outlet basin. In the case of Las Piedritas, we tested several initial locations. One from the farthest place on the basin, others from the lateral walls. All of them resulted in almost the same pile height and flow ve- locity at the basin outlet. The basin of Colorado received the Florencia-North stream as well. Thus, we locate piles both at the top of the Colorado basin and at the top of the FlorenciaNorth stream. In the case of Florencia-South, the initial pile was located at the top of its basin.

An additional pile was located at the top of the La Ponderosa Basin, just to test whether lahars could reach the town. However, this site has no collected data about the deposited ash volumes. We assumed the same volumes as in Florencia Creek due to the size of this basin being similar.

\section{Results}

In order to run Two-Phase-Titan, a DEM is needed. The Argentine Comisión Nacional de Actividades Espaciales (COANE) initially provided us with two $15 \mathrm{~m}$ resolution DEMs. One of them was developed from optical satellite images and the second one from radar satellite images.

In order to test the DEMs, we used the initial data set for Florencia Creek. Orange contours in Fig. 8 show the predictions of Two-Phase-Titan using the DEM based on optical sensors, and the red contours shows the prediction using the DEM built from radar sensors. The Google-Earth image shows extensive forest that hides the Florencia Stream from view. The optical DEM reproduces this effect showing the terrain flatter than it actually is. For this reason the model predicts that the lahar will be widely spread from the beginning. In contrast, using the radar-based DEM, the flow follows the actual natural channel hidden by the trees. In addition, the boundary of the forest is represented in the model as an abrupt change in the topography. This is the case for some locations in Villa la Angostura, where patches of more than $30 \mathrm{~m}$ high forest have been cleared to allow human settlements. Thus, the program predicts a diversion of the flow where such a barrier is reached (see the arrow in Fig. 8), while the flow just follows the natural channel in the prediction done by the program using the radar based model.

Therefore, the optic sensor based terrain model was replaced by the more accurate radar sensor based DEM. As explained above, we use two initial conditions. One with high volumes and the second one with medium volumes (see values in Table 1). Figure 9 shows the prediction of Two-PhaseTitan for the medium volumes. In this case, none of the flows reach the urban area. Nevertheless, water treatment facilities and spare living houses could be inundated. For the volume used in La Ponderosa Creek, Two-Phase-Titan predicts that the flow could inundate the main road and structures built near it. It is informative to see that the flow from Piedritas Creek inundates part of a planned urban expansion zone. However, the flow is diverted at an almost $90^{\circ}$ angle seemingly by a topographic barrier.

In the case of high volumes, the urban area is shown to be reached by the flows from Florencia Creek (see Fig. 10). We paid special attention to the possibility that the school 


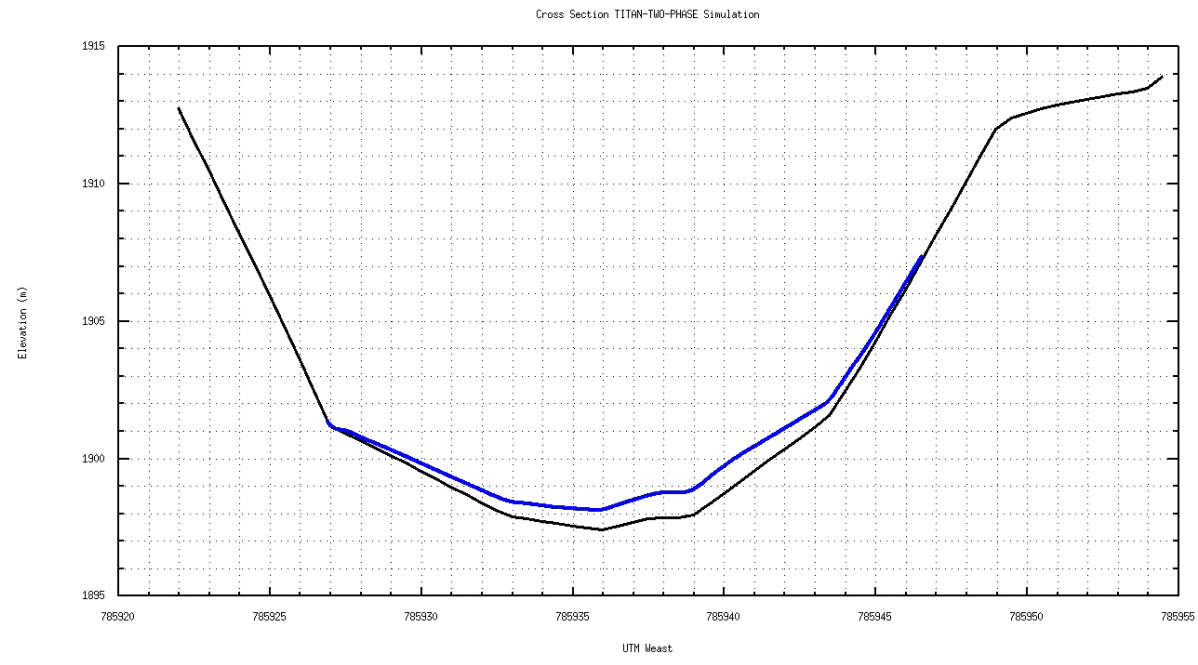

Figure 5. Cross-section of predicted super-elevation of the 2005 Vazcun Valley lahar at El Salado Baths. The black line represents the topography and the blue one the surface of the flow. Two-Phase-Titan predicts $6.5 \mathrm{~m}$ super-elevation.

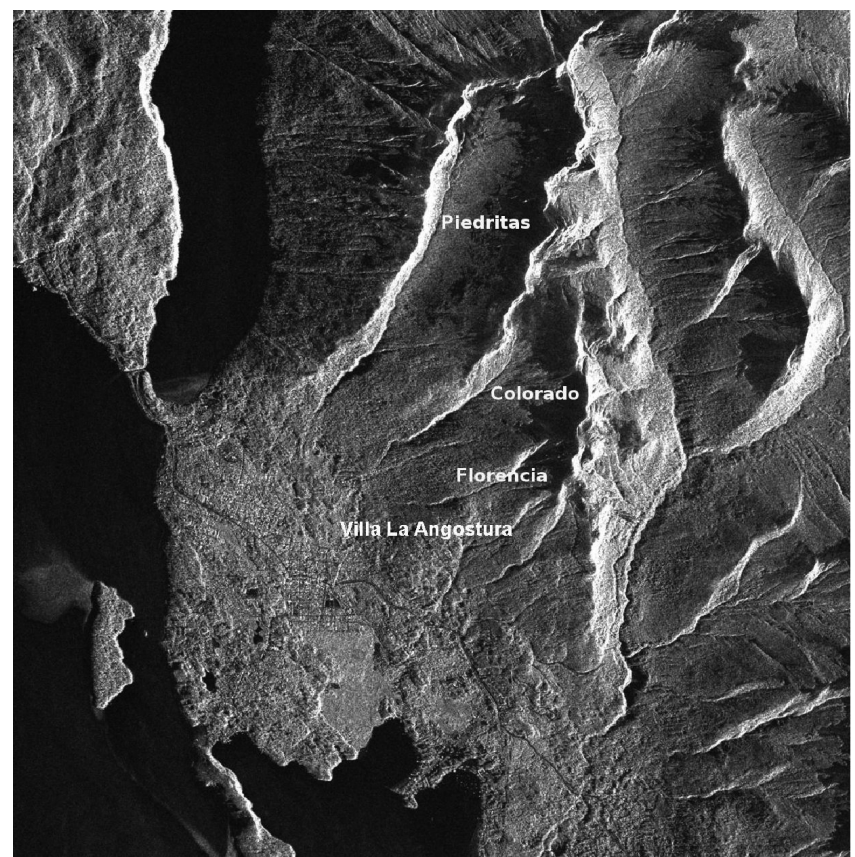

Figure 6. Satellite view of the area of Villa la Angostura, showing the three streams that enter the urban part of the town (Image courtesy of Comisión Nacional de Actividades Espaciales, CONAE).

named School 186 might become affected, as shown by the circle filled in blue. Based on the prediction of the program, we advised the local government authorities of the city to take appropriate decisions about that possibility. As a result, the mayor ordered temporary relocation of the children to another school located in a safer place. In the cases of Colorado and La Ponderosa, the runout of the flow is almost the same as in the medium volume case. Nevertheless, they tend

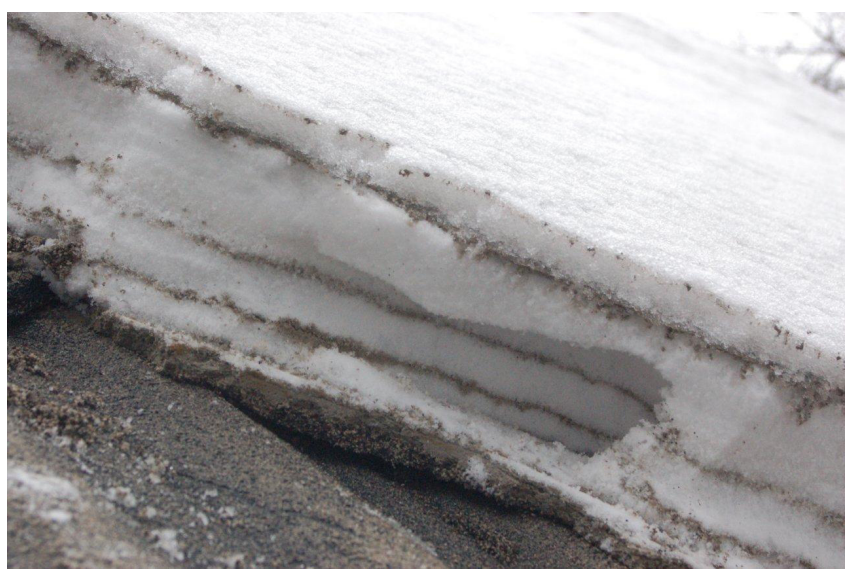

Figure 7. Interlayered ash-snow deposit on the nearby mountains of Villa la Angostura. The total deposited thickness is less than $1 \mathrm{~m}$. The ash corresponds to almost $30 \%$ of the thickness.

to inundate in a more expanded way, showing larger inundation areas than in the case of medium volumes. Fortunately, these increase in the inundation area occur in low population zones.

In the case of Las Piedritas Creek, we located the initial pile at the highest place of the basin. The flow shows a meandering behaviour until it reaches the middle of the basin. From that point, its behavioural characteristics become similar to the case of medium volumes but with greater depth at each point. Then, despite of the high volume used, the program shows that the flow apparently diverted in the same fashion as in the medium volume case. Field inspection of the place where the modelled diversion occurs found no such topographic barrier. Instead, there is a narrow opening in the hills. Thus, the prediction of Two-Phase-Titan about the path 


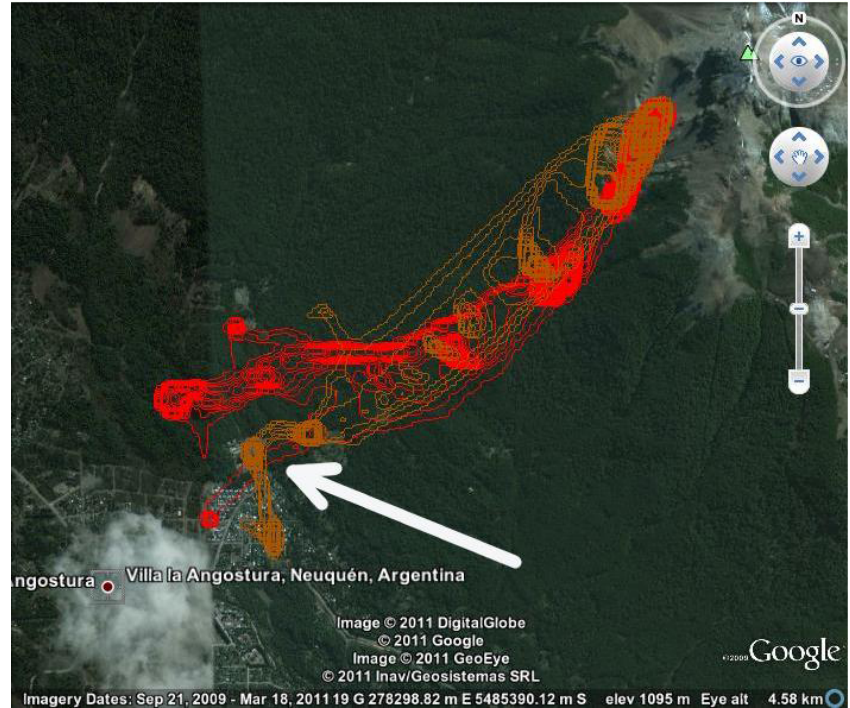

Figure 8. Two-Phase-Titan predictions using two DEMs on a Google-Earth image. The orange contours shows the prediction of the lahar inundation using the DEM based on optical sensors. The red contours shows the prediction of the lahar inundation using a DEM developed from radar sensors. The white arrow points to a beginning of the forest that seems to divert the flow, because it is seen by the optical-based DEM as a wall.

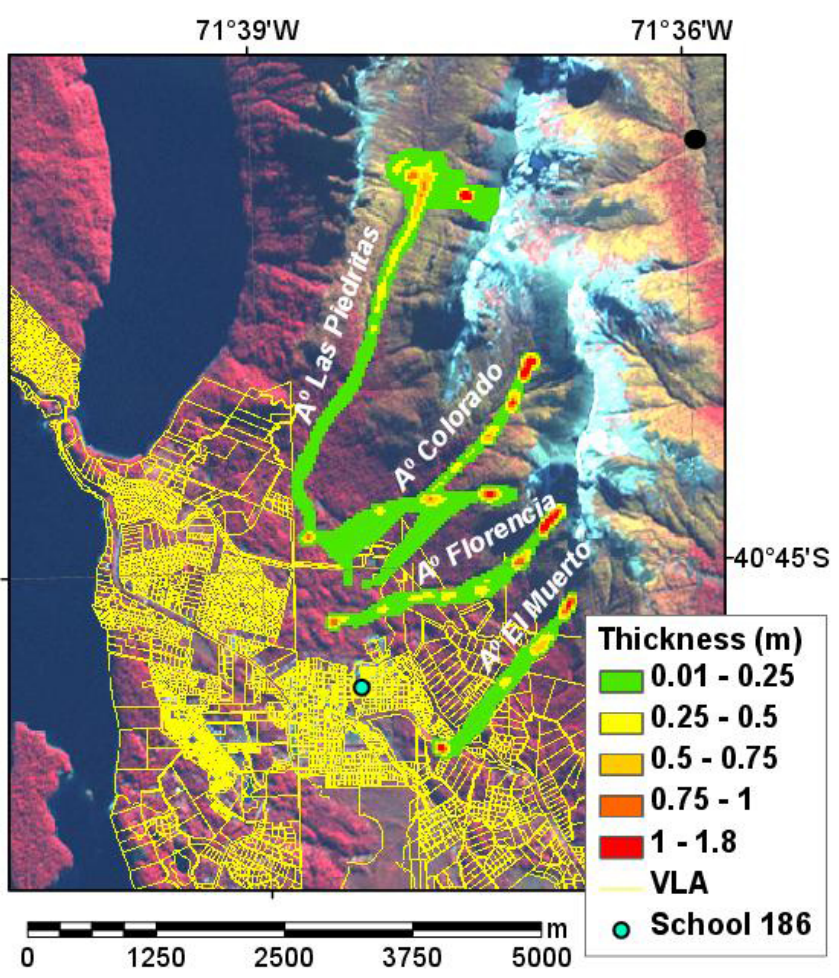

Figure 9. Predictions of Two-Phase-Titan of lahar thickness and runout for medium size volumes.

followed by the flow was mistaken, probably because the $15 \mathrm{~m}$ DEM was flattening the representation of the terrain.

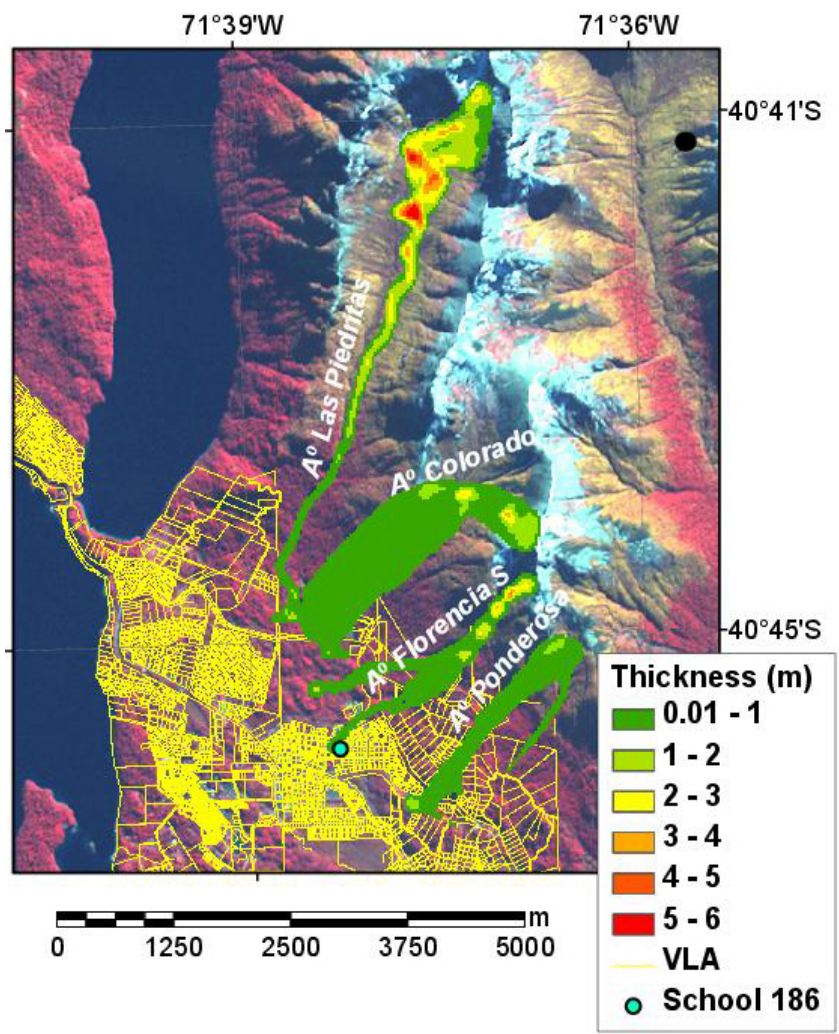

Figure 10. Predictions of Two-Phase-Titan of lahar thickness and runout for large size volumes.

We decided to test whether, by using a more accurate DEM, the prediction would become more realistic. For this purpose the Comisión Nacional de Actividades Espaciales (CONAE), developed a $10 \mathrm{~m}$ resolution DEM, which was used to repeat the medium volume predictions. Figure 11 shows a Google-Earth image of Villa la Angostura with the medium size modelled lahars using that DEM. The initial piles ware located at the top of the basins of Las Piedritas, Colorado and Florencia creeks. In this case the flow from Las Piedritas followed the narrow path, predicting that the flow could reach the outskirts of the urban area. The prediction for Colorado Creek is similar to the corresponding prediction done using the $15 \mathrm{~m}$ DEM. In the case of Florencia Creek, the prediction shows that the flow could go through the whole of the School 186 neighbourhood, even reaching the highway.

\section{Verification}

The general results of the model were validated and verified with typical analytical 1-D solutions and with field data from experiments on artificial channels, as can be seen in Córdoba et al. (2015) as well as with real-scale flows (see above for a comparison with Vazcun Valley lahar). To date, lahars of the size accounted for by our predictions have not 


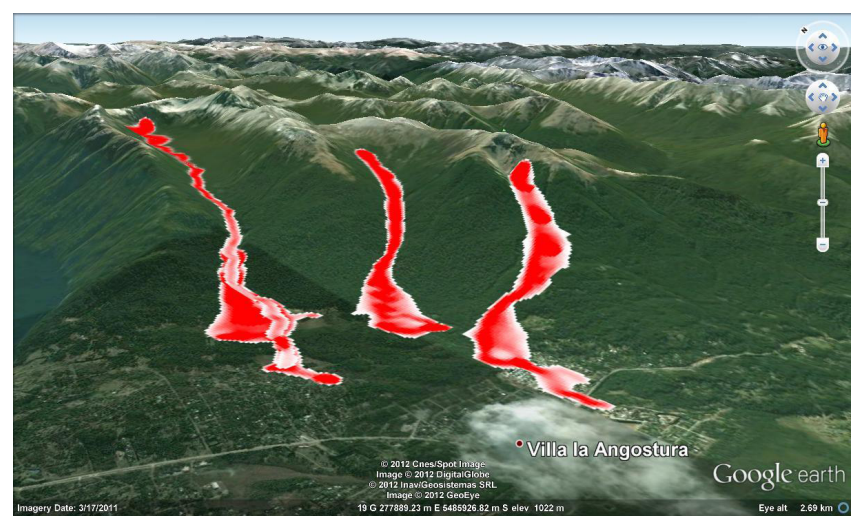

Figure 11. Prediction of Two-Phase-Titan of lahar thickness and runout using the $10 \mathrm{~m}$ resolution DEM built by the CONAE.

occurred yet in the three main studied basins (Colorado, Florencia and Piedritas). However, on 22 January 2012 a very small lahar occurred on El Muerto (La Ponderosa) Creek. Has et al. (2012) reported an initial thickness of the pile of $1.6 \mathrm{~m}$, estimated from the height of a natural dam that acted as a barrier that stopped two initial flows. The trigger mechanism for the lahar formation was the rupture of this natural dam. The flow began to stop with a front height of $1.3 \mathrm{~m}$. The width of the flow was estimated in some places at from 0.8 to a maximum of $10 \mathrm{~m}$. The Has et al. (2012) report does not inform about volumes. Figure 12 shows a comparison of our predictions for medium volumes (Fig. 9) in that creek. The prediction of Two-Phase-Titan shows a more laterally spread flow with less lahar thickness. Our prediction about runout is greater than the actual flow runout. Although the report does not provide information about volumes, a from a quick estimate from the Has et al. (2012) photographs, slopes, sections and pile heights we calculate that the volume is small (less than $10000 \mathrm{~m}^{3}$ ). The difference in spread shows that in order to reproduce small volume flows a more accurate DEM is necessary, as both DEMs used (10 and $15 \mathrm{~m}$ ) have a resolution that does not allow us to see the actual flow and channel width because they are of smaller width than the DEMs pixel. Nevertheless, the flow is within the range of our prediction.

On the other hand, the snow avalanche reported by Fauqué et al. (2011) cannot be used for model verification, because modelling snow avalanches is out of the scope of Two-PhaseTitan, whose aim is modelling two-phase lahars (Córdoba et al., 2015).

\section{Conclusions}

Although Villa La Angostura is located in a mountainous environment and conditions for secondary lahars were present, only minor mass waste events were recorded. Destructive mass waste events involving tephra deposits triggered by intense precipitation were reported in distal locations in

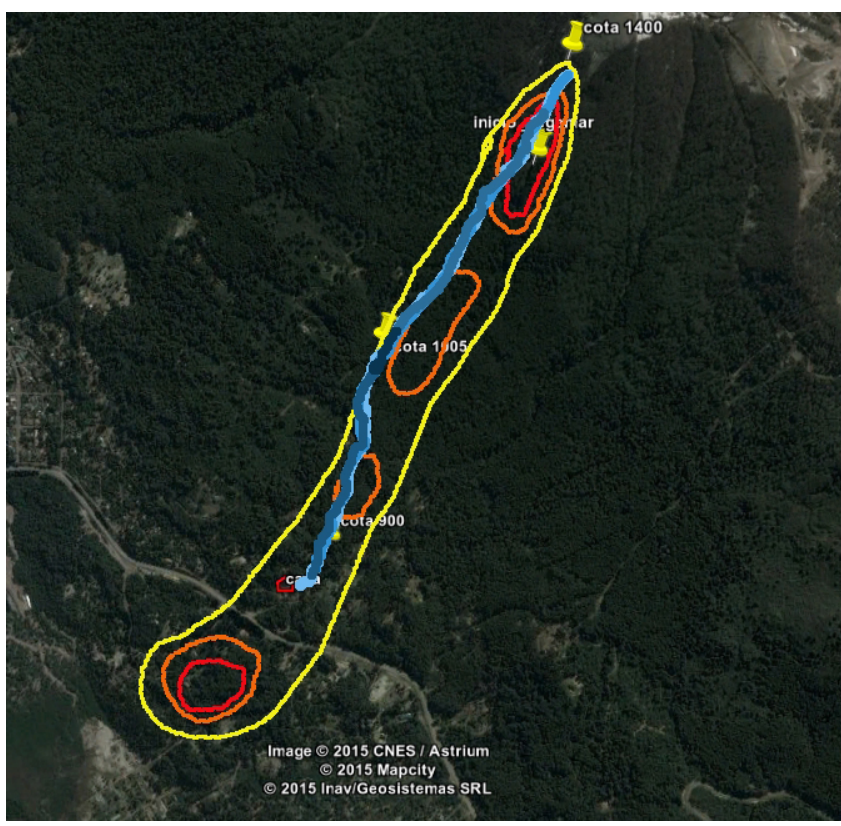

Figure 12. Comparison between the predictions of Two-PhaseTitan and the actual lahar of 22 January 2012. The yellow line shows the predicted border of the flow for medium volumes. The orange line shows a flow depth of $0.75 \mathrm{~m}$. The red lines show flow depths up to $1.8 \mathrm{~m}$. The red square shows the house in front of which the actual flow stopped (shown in one of the pictures in Has et al., 2012). The blue line shows the path and width of the 22 January 2012 lahar.

the Patagonian Steppe ( $100 \mathrm{~km}$ east of Villa La Angostura) where annual average rainfall is less than $600 \mathrm{~mm}$ (Wilson et al., 2013).

This work draws attention to secondary lahars as a real hazard not only in volcanic proximal areas, but also in broad regions of Andean Patagonia under the influence of explosive volcanic activity, even though from the volcanological and the tephra deposits perspective, they are considered as medial to distal facies. It also proposes a valid method to evaluate critical hazardous areas in dense forested urban environments that are typical in the region.

Although at this point this is not a probabilistic tool, results of the presented modelling provide a good evaluation of lahar susceptibility and set the basis for future development of a probabilistic approach.

The output of the modelling is a valuable tool for city planning and risk management especially considering the physical characteristics of Villa La Angostura area, the strong urban development growth and the land occupation tendencies observed in the last decade.

In forested areas, the availability of a DEM produced from good radar data is critical in order to get the minimal resolution required for the modelling. In addition, through our numerical experiment results, we support the work of Capra et al. (2011) and Stefanescu et al. (2012) related to the impor- 
tance of the precision of the DEM in forecasting the spread and runout distances of modelled flows.

Author contributions. G. Córdoba and M. Sheridan developed the program TWO-PHASE-TITAN. In addition, G. Córdoba worked in the modelling with Gustavo Villarosa and D. Beigt. G. Villarosa conducted field work and contributed with the geological background and data interpretation. D. Beigt co-operated with photointerpretation and GIS mapping. Jose Viramonte helped in the geologic interpretation. G. Salmuni developed the DEMs at CONAE.

Acknowledgements. The authors wish to thank Marcos Arretche, David Tressens, Emilio Molla and staff of Civil Protection Agency, who supported this study. The Argentinean Aerospace Agency (CONAE) developed and allowed G. Salmuni to provide us with the requested DEMs. The Universidad de Nariño, Colombia, allowed the mobility of G. Córdoba and gave him the necessary time for this research. Project 04 B155 funded by Universidad Nacional del Comahue partially covered field work and initial on site modellings. Aerolineas Argentinas provided the return trip of G. Córdoba to travel from Colombia to Bariloche, Argentina.

Edited by: A. Costa

Reviewed by: two anonymous referees

\section{References}

Barros, V. R., Cordon, V. H., Moyano, C. L., Méndez, R. J., Forquera, J. C., and Pizzio, O.: Cartas de precipitación de la zona oeste de la Provincia de Rio Negro y Neuquén, Informe de la Facultad de Ciendcias Agrarias, Universidad Nacional del Comahue, Neuquén, Argentina, 1983.

Baumann, V., Elissondo, M., Fauqué, L., and Gonzáles, R.: Peligro de generación de flujos de detritos o lahares secundarios en Villa la Angostura, Informe preliminar, Servicio Geológico Mimero Argentino, SEGEMAR, Buenos Aires, Argentina, internal Report, 2011.

Capra, L., Manea, V. C., Manea, M., and Noromi, G.: The importance of digital elevation model resolution on granular flow simulations: a test case for Colimavolcano using TITAN2D computational routine, Nat. Hazards, 59, 665-680, 2011.

Chow, V. T.: Open channel hydraulics, McGraw Hill, New York, USA, 700 pp., 1969.

Colebrook, C. and White, C.: Experiments with fluid friction in Roughened pipes, Proc. Roy. Soc. London, 161, 367-381, 1937.

Collini, E., Osores, M. A., Folch, A., Viramonte, J. G., Villarosa, G., and Salmuni, G.: Volcanic ash forecast during the June 2011 Cordón Caulle eruption, Nat. Hazards, 66, 389-412, 2013.

Córdoba, G., Sheridan, M., and Pitman, B.: A two-phase, depthaveraged model for geophysical mass flows in the TITAN code framework, 28th IUGG Conference on Mathematical Geophysics, Pisa, Italy, 7-11 June, 2010.

Córdoba, G., Sheridan, M. F., and Pitman, B.: TITAN2F: A pseudo3D Model of 2-phase Debris Flows, Nat. Hazards Earth Syst. Sci. Discuss., submitted, 2015.
Coulomb, C.: Mémoires fe Mathematique et de Physique, in: Vol. VII, chap. Essai sur une application des règles de maximis and minimis à quelques problèmes de statique, relatifs à l'architecture, Annèe, Paris, 343-382, 1773.

Elissondo, M., Gomzales, R., Sruoga, P., Fauqué, L., Tejedo, A., Alonso, S., Carrizo, R., Herrero, J., Murruni, L., Ojada, E., Sánchez, L., and Costado, C.: Erupción del 4 de Junio de 2011 del Cordón Caulle, Chile y su impacto ambiental en territorio argentino, Tech. rep., Servicio Geológico y Minero Argentino, SEGEMAR, Buenos Aires, Argentina, internal Report, 2011.

Fauqé, L., Baumann, V., and Gonzáles, R.: Comentarios sobre la observación de una avalancha de nieve encauzada en la quebrada Florencia, Villa la Angostura, Neuquén, Servicio Geológico Argentino, SEGEMAR, Buenos Aires, Argentina, internal Report, 2011.

Folch, A., Costa, A., and Macedonio, G.: An automatic procedure to forecast tephra fallout, J. Volcanol. Geoth. Res., 177, 767-777, 2008.

Guo, Z.: Velocity-depth coupling in shallow-water flows, J. Hydraul. Eng., 121, 717-724, 1995.

Has, R., Calderón, P., Sandoval, C. and Molla, E.: Evento 22 Enero de 2012, Grupo de Rescate de Montaña Villa la Angostura, Reporte a Intendente Roberto Cacault, Argentina, Internal Report, 2012.

Iverson, R.: The physics of debris flows, Rev. Geophys., 35, 245 296, 1997.

Iverson, R. and Denlinger, R.: Flow of variably fluidized granular material across three-dimensional terrain 1: Coulomb mixture theory., J. Geophys. Res., 6, 537-552, 2001.

Lara, L. E. and Moreno, H.: Geoloía del Complejo Volcánico Puyehue-Cordón Caulle, Región de Los Lagos, Chile, Carta geológica de Chile, Serie Geología Básica No. 99, Servicio Geoógico y Minero de Chile, Santiago, Chile, 2006.

OVDAS-SERNAGEOMIN: Reporte Especial de Actividad Volánica, Internal report 13, OVDAS-SERNAGEOMIN, Arica, Chile, 2011a.

OVDAS-SERNAGEOMIN.: Reporte Especial de Actividad Volánica, Internal report 28, OVDAS-SERNAGEOMIN, Chile, 2011b.

Savage, S. and Hutter, K.: The motion of a finite mass of granular material down a rough incline, J. Fluid Mech., 199, 177-215, 1989.

Stefanescu, E. R., Bursik, M., and Patra, A. K.,: Effect of digital elevation model on Mohr-Coulomb geophysical flow model output, Nat. Hazards, 62, 635-656, 2012.

Villarosa, G. and Outes, V.: Efectos de la caída de cenizas del Complejo Volcánico Puyehue (CPCC) sobre la región del lago Nahuel Nuapi., chap. La erupción del Cordón Caulle del 4 de junio de 2011: Mapa de distribución, características de la ceniza volcánica caída en la región e impactos en la comunidad), Universidad del Comahue, Bariloche, Argentina, convenio de Asistencia Técnica Centro Regional Universitario Bariloche, Argentina, 12-59, 2013.

Villarosa, G., Outes, V., Hajduk, A., sellés, D., Fernández, M., Montero, C., and Crivelli, E.: Explosive volcanism during the Holocene in the upper Limay river basin: The effects of ashfalls on human societies, Northern Patagonia, Argentina, Quat. Int., 158, 44-57, 2006. 
Villarosa, G., Schneider, M., Outes, V., López, E., Dzendoletas, M. A., Beigt, D., Villarosa, F., Galosi, C., and Ruiz, M.: Estudio de Peligrosidad de avalanchas en el Parque Nahuel Huapi vinculados a la erupción del Cordón Caulle (CC), Informe Final, Asesoría Institucional, Convenio CONICET - Administración de Parques Nacionales, Argentina, 81 pp., 2012.

Williams, R., Stinton, A. J. and Sheridan, M. F.: Evaluation of the Titan2D Two-Phase Flow Model Using an Actual Event: Case study of the 2005 Vazcún Valley Lahar, J. Volcanol. Geoth. Res., 177, 760-766, 2008.
Wilson, T., Stewart, C., Bickerton, H., Baxter, P., Outes, V., Villarosa, G. and Rovere, E.: Impacts of the 2011 Puyehue Cordón Caulle volcanic complex on urban infrastructure, agriculture and public health, GNS Science Report 2012/20, 88 pp., 2013. 